\title{
Variance components and association between corn hybrids morpho-agronomic characters
}

\section{Componentes de variância e associação entre caracteres morfoagronômicos em híbridos de milho}

\author{
Velci Queiróz de SOUZA'; Diego BARETTA²; Maicon NARDINO³; Ivan Ricardo CARVALHO ${ }^{4}$; \\ Diego Nicolau FOLLMANN"; Valmor Antônio KONFLANZ5; Denise SCHMIDT ${ }^{6}$ \\ ${ }_{1}^{1}$ Professor Dr. Universidade Federal de Santa Maria, Campus de Frederico Westphalen. velciq@gmail.com \\ ${ }^{2}$ Pós Graduando em Agronomia - Universidade Federal de Pelotas (UFPel). barettadiego@gmail.com \\ 3 Autor para correspondência. Pós Graduando em Agronomia - Universidade Federal de Pelotas (UFPel). \\ nardinomn@gmail.com \\ ${ }^{4}$ Mestrando do Programa de Pós Graduação em Agronomia, Agricultura e Ambiente, Universidade Federal de Santa \\ Maria, Campus de Frederico Westphalen. carvalho.irc@gmail.com; diegonicolaufollmann@gmail.com \\ ${ }^{5}$ Professor Dr. da Universidade do Oeste Catarinense, (UNOESC) Campus de Campos Novos- SC. \\ valmor@kspsementes.br \\ ${ }^{6}$ Professor Dra. Universidade Federal de Santa Maria, Campus de Frederico Westphalen. denise@ufsm.br
}

Recebido em: 17-07-2014; Aceito em: 10-02-2015

\begin{abstract}
The present work aimed at evaluating the canonical correlations between traits of grain yield and morphological traits in maize, in order to verify the associations and interdependence among groups. The experiment was conducted in the agricultural year 2010/2011; consisted of 25 corn hybrids, allocated in five locations of the states of Paraná, Santa Catarina e Rio Grande do Sul. Settled two groups of traits, with Group I comprised agronomic characters of grain yield: grain yield plot, the total weight of grains and weight of hundred grains and the group II formed by morphology: stem diameter, leaf angle, tassel length, number of tassel branches, total leaf area, insertion of the ear, plant height in maize. The first, second and third canonical pair proved significant at the $1 \%$ level of probability, using the chi-square test, indicating that the groups are not independent. Hybrids with higher plant height, insertion of ear and leaf angle and fewer branches and tassel length are associated with the increase in weight of hundred grains in maize. To increase the grain weight, should be considered hybrids with greater insertion of the ear, leaf area and shorter length of the tassel. The increase in leaf area, as well as smaller tassel length is related positively to increase grain yield in maize.
\end{abstract}

Additional keywords: associations between characters; multivariate analysis; Zea mays $\mathrm{L}$.

\section{Resumo}

O presente trabalho objetivou avaliar as correlações canônicas entre caracteres que compõem o rendimento de grãos e caracteres morfológicos em milho, visando a verificar as associações e a interdependência entre os grupos. O experimento foi conduzido no ano agrícola de 2010/2011, compreendido por 25 híbridos simples de milho, alocados em cinco locais dos Estados do Paraná, Santa Catarina e Rio Grande do Sul, Brasil. Estabeleceram-se dois grupos de caracteres, sendo o grupo I formado por caracteres agronômicos que compõem o rendimento de grãos: rendimento de grãos da parcela $(R G)$, massa total de grãos da espiga (MG) e massa de cem grãos (MCG), e o grupo II formado por caracteres morfológicos: diâmetro do colmo (DC), ângulo de folha $(\mathrm{AF})$, comprimento do pendão (CP), número de ramificações do pendão (NR), área foliar total (AFT), altura da inserção da espiga (AE) e altura de planta (AP) em milho. O primeiro, o segundo e o terceiro pares canônicos revelaram-se significativos a nível de $1 \%$ de probabilidade, pelo teste qui-quadrado, indicando que os grupos não são independentes. Híbridos com maiores altura de plantas, de inserção de espiga e ângulo foliar e menor número de ramificações e comprimento do pendão estão associados com o incremento da massa de cem grãos em milho. Para incremento de massa de grãos, devem ser considerados híbridos com maior altura da inserção da espiga, área foliar e menor comprimento do pendão. $O$ aumento da área foliar, assim como menor comprimento do pendão, está relacionado favoravelmente para o aumento do rendimento de grãos em milho.

Palavras-chave adicionais: análise multivariada; associações entre caracteres; Zea mays L. 


\section{Introduction}

Corn, due to the high nutritional value, adaptability to different soil and climatic conditions and high yields that can be achieved, is one of the most cultivated cereals in the world, having great social and economic importance. The culture has significant impact for being used as a food, fiber, fuel and feed source. The cereal is used as an ingredient of a list of numerous industrial products, besides used in the nutrition of the world population (Hallauer et al., 2010).

Brazil stands out as one of the world's largest corn producers, surpassed only by the United States and China. According to a survey conducted by CONAB, in the $2013 / 2014$ crop, Brazil's corn production was of 75.19 million tons in 15.32 million hectares, with an average yield of $4.902 \mathrm{~kg} \mathrm{ha}^{-1}$ (CONAB, 2014). However, the national average corn yield is well below the desired, considering that culture has a high yield potential and can achieve yields higher than $16 \mathrm{t} \mathrm{ha}^{-1}$ grains in experimental conditions or by farmers who adopt appropriate management technologies (Embrapa, 2010).

Despite gains obtained through plant breeding, difficulties still persist in promising hybrids selection process. Important contributions to obtain genetic progress in plant breeding are the need for the establishment of artificial selection criteria that are efficient and statistical analyzes that may help in choosing the best selection strategy, what makes tools for better understanding of the genetic relation between characters important (Carvalho et al., 2001).

During the selection process in search of superior genotypes, the objective is to simultaneously identify multiple characters, and correlation estimates knowledge may help in the selection of a desired plant ideotype, maximizing efficiency on selection gains. However, the linear correlation does not allow assessing the interrelations between two groups of variables determined by a larger number of characters. In order to overcome this difficulty, one of the used techniques is the canonical correlation analysis, which allows assessing the interrelations between two complexes determined by an arbitrary characters number. In the upgrade, cases where it is important to assess the relation between, for example, aerial part characters area versus root system, agronomic characters versus physiological characters, primary components versus secondary production components, etc. are cited as possibilities of using this methodology (Cruz et al., 2012).

There are studies that used the canonical correlation analysis in different cultures, such as: papaya tree (Brum et al., 2011), potato (Rigão et al., 2009), sugar cane, (Silva et al., 2007), Eucalyptus (Protásio et al., 2012, Trugilho et al., 2003) and bean (Coimbra et al., 2000).

Exploratory studies to better understand the associations between agronomic characters of interest in corn crops can help to define strategies to increase breeding programs efficiency, since there is large number of characters that researchers have at selection time. In this context, the objective of this study was to evaluate the canonical correlations between corn grain yield characters and morphological characters, in order to verify the associations and the interdependence between groups.

\section{Material and methods}

Artificial crosses between inbred lines were conducted at KSP Sementes Ltda. company research station, in the city of Clevelãndia-PR in the 2010/2011 agricultural year. To conduct the study, 15 inbred lines were used as female parents, with high grain yield characteristics and eight inbred lines as male parents, with rusticity features, forming two distinct heterotic groups, derived from KSP Sementes Ltda. company germplasm. Heterotic groups were artificially crossed according to the partial diallel model, thus resulting in 25 hybrid combinations. Hybrid seeds obtained from crosses groups were harvested by hand, dried and prepared for tests sowing. The 25 hybrids were obtained by the following combinations between lines: $1 \times 1,1 \times 4$, $2 \times 3,3 \times 1,3 \times 4,4 \times 3,4 \times 7,4 \times 6,5 \times 3,5 \times 4,6 \times 3,6 \times 4,7 \times 4$, $8 \times 4,9 \times 4,10 \times 5,11 \times 3,12 \times 3,13 \times 3,13 \times 4,14 \times 4,15 \times 3$, $15 \times 5,15 \times 8$ and $15 \times 2$.

Tests sowing were conducted in the $2011 / 2012$ season in five locations of the three Brazilian southern states. In Rio Grande do Sul, the test was conducted in the city of Frederico Westphalen, (27²3'47"S, $\left.53^{\circ} 25^{\prime} 35^{\prime \prime W}, 480 \mathrm{~m}\right)$. In Santa Catarina, the test was conducted in the municipality of Itapiranga (27ำ10'10"S, 5342'44"W, $206 \mathrm{~m}$ ), and in Paraná the tests were conducted at three sites; Pato Branco (26 $6^{\circ} 13^{\prime} 44^{\prime \prime S}$, $52^{\circ} 40^{\prime} 15^{\prime \prime} \mathrm{W}, 760 \mathrm{~m}$ ), Ampére (2554'20"S, 5325'54"W, $718 \mathrm{~m})$ and Clevelândia (26² $21^{\prime} 17^{\prime \prime} \mathrm{S}, 5^{\circ} 28^{\prime} 56^{\prime \prime} \mathrm{W}$, $860 \mathrm{~m})$.

The experimental units were composed of two lines with five meters long, spaced with $0.70 \mathrm{~m}$. The sowing lines were marked with "direct sowing" system seeder, with lines fertilization being performed in the same operation. Hybrid seeds from the crosses were sown manually. Sowing time was carried out according to the agroclimatic zoning of each site. Soil management and cultural practices were the same for the five sites, obeying phenological stages and culture needs, where after emergence and crop establishment, hand thinning was held, for stand adjustment of 42 plants per experimental unit, which is equivalent to 60.000 plants $\mathrm{ha}^{-1}$.

The following agronomic characteristics were measured: stem diameter (SD, in $\mathrm{mm}$ ), leaf angle (LA, in degrees), tassel length ( $T L$, in $\mathrm{cm}$ ), tassel branches number (BN, in units), total leaf area (TLA, in $\left.\mathrm{cm}^{2}\right)$, ear insertion height $(\mathrm{EH}$, in $\mathrm{cm})$, plant height $(\mathrm{PH}, \mathrm{cm})$, plot grain yield ( $\mathrm{GY}$, in $\mathrm{kg}$ ), ear grains total mass (GM, in g) and a hundred grains mass (HGM, in g). Two characters groups were established, with group I formed by grain yield agronomic characters, i.e., plot grain yield (GY), ear grains total mass (GM) and a hundred grains mass 
(HGM), and group II formed by morphological characters, i.e., stem diameter (SD), leaf angle (LA), tassel length $(T L)$, tassel branches number $(B N)$, total leaf area $(T L A)$, ear insertion height $(E H)$ and plant height $(P H)$ in corn.

Genetic correlations were estimated $\left(r_{G}\right)$ between analyzed characters, as described by Hazel (1943). Covariance components for each variables pair $(x$ and $y$ ) were obtained through the mean products (MP) of genotype (G) and residue (E) variation sources, through the expression:

$\mathrm{MP}_{x y}=\left(\mathrm{MS}_{x+y}-\mathrm{MS}_{x}-\mathrm{MS}_{y}\right) / 2$

which equals to covGXY $=\left[\left(\sigma^{2} x+y-\sigma^{2} x-\sigma^{2} y\right) / 2\right]$ and estimators:

$$
\begin{aligned}
& \sigma^{2} G_{X Y}=\left(M P_{G}-M P_{E}\right) / r \\
& \sigma^{2} G_{X}=\left(M S_{G_{X}}-M P_{E_{X}}\right) / r \\
& \sigma^{2} G_{Y}=\left(M S_{G_{y}}-M P_{E_{y}}\right) / r
\end{aligned}
$$

Where, MPXY is the mean product obtained between $x$ and $y$ variables; $M S_{x+y}$ is related to $x$ and $y$ variables mean square; $\operatorname{Cov}_{x y}$ is the covariance obtained between $x$ and $y$ variables; $\sigma^{2} G x$ refers to the $x$ or $y$ variables genetic variance, $\mathrm{MS}_{G_{x}}$ ou $\mathrm{MS}_{G_{y}}$ : $\mathrm{x}$ or $\mathrm{y}$ variable genotype mean square; $\mathrm{MP}_{\mathrm{E}}, \mathrm{x}$ or $\mathrm{y}$ residual effect; r: repetitions number.

The estimators were obtained from genotype (G) and residue (E) MS to $x$ and $y$ variables of the analysis of variance table (ANOVA), resulting in the genetic correlation:

$r G=\sigma^{2} G X Y /\left(\sigma^{2} G \times \times \sigma^{2} G Y\right)^{1 / 2}$

Where: $r_{G}=$ genetic correlation; $\sigma^{2} G x Y$ : $x y$ genetic variance; $\sigma^{2} G x$ : $x$ variable genetic variance; $\sigma^{2} G$ : $y$ variable genetic variance.

Correlation coefficients were obtained as described by Mode \& Robinson (1959). Correlations significance were assessed by $t$ test $p=0.05$ and 0.01 , as described by Steel \& Torrie (1980).

Canonical correlations were estimated between group I, where grain yield agronomic characters were allocated (GY, GM and HGM) and group II, composed of morphological characters (SD, LA, CFB, DUN, TL, BN, TLA, EH and PH) in corn, according to the procedures described by Cruz et al. (2012).

The null hypothesis:

$H_{0}: \rho_{1}=\rho_{2}=\ldots \ldots=\rho_{n}=0, s=\min \{p, q\}$

can be evaluated using the chi-square approximate test $\left(x^{2}\right)$, which is given by:

$X^{2}=-t \log _{e}\left[I_{i=1}^{s}\left(1-r_{i}^{2}\right)\right]$

where:

$\mathrm{t}=\mathrm{n}-0.5(\mathrm{p}+\mathrm{q}+3)$;

$\mathrm{n}=$ number of experimental observations; and

$p+q=$ represents $p$ or $q$-th estimated correlation.

Genetic parameters estimates were carried out based on the REML procedure, using the Selegen software (Resende, 2007). To obtain the estimates, the 54 model was used. The other analyzes were performed using Genes Windows version (Cruz, 2006).

\section{Results and discussions}

The results of the variance components and genetic parameters related to the joint analysis of five cultivation sites are presented in Table 1. As for being complex inheritance characters, with large environment influence, genetic variance estimates $\left(\sigma^{2} G\right)$ revealed that characters analyzed in the five culture environments showed genetic control rates ranging from $30.94 \%$ to BN character to $4.20 \%$ for GM in relation to total phenotypic variance, indicating the existence of genetic variability among genotypes, allowing to infer good chances of success in the selection of superior hybrids. Genetic structure knowledge through variance components estimates, allows to quantify active variances on characters. Such information allow to understand characters genetic inheritance, quantifying phenotypic, environment and genetic components, enabling to direct the breeder about the improvement method, which function as facilitators in the selection process as theoretical framework, to further nominate and recommend commercial hybrids (Maia et al. 2009).

Heritability is a genetic parameter of great importance, because it quantifies the fraction of heritable phenotypic variation, which can be exploited in the selection (Rosado et al., 2012). The genotype mean heritability $\left(\hat{\mathrm{h}}_{\mathrm{mg}}^{2}\right)$ showed values ranging from 0.17 for $\mathrm{GM}$ to 0.81 for $\mathrm{BN}$, which according to Resende (2002), low heritability such as observed for GM (0.17) expresses the highest environmental influence on the character, making the selection process difficult. This parameter is estimated when using means such as evaluation/selection units, where a significant precision level is reached, minimizing experimental errors by increasing the repetitions number. Consequently, this is the interest parameter for projecting breeding success, since genotypes are selected considering its predicted genotypic values based on several repetitions means (Maia et al., 2009).

There was low individual heritability in the broad sense $\left(\hat{h}_{a}^{2}\right)$, free of interaction with locals between all characters, revealing high influence of GxA interaction variance, since this parameter is generated by the $\sigma^{2} G / \sigma^{2} \mathrm{P}$ quotient (genetic variance/phenotypic variance), what shows the importance of the deployment of this interaction to maximize gains in superior genotypes selection. Estimates of this magnitude are due to this being quantitative characters, with complex inheritance, conditioned by many genes with small individual effects and heavily influenced by the environment (Cruz et al., 2012). 
Table 1 - Estimates of genetic parameters (individual REML) for agronomic characters in 25 corn hybrids, referring to the five sowing sites in the Southern region.

\begin{tabular}{|c|c|c|c|c|c|c|c|c|c|c|}
\hline \multirow{3}{*}{ Estimation } & \multicolumn{9}{|c|}{ Assessed characters ${ }^{(2)}$} & \multirow{3}{*}{$\begin{array}{c}\text { HGM } \\
(\mathrm{g})\end{array}$} \\
\hline & $\mathrm{SD}$ & LA & $\mathrm{TL}$ & $\mathrm{BN}$ & TLA & $\mathrm{EH}$ & $\mathrm{PH}$ & GY & GM & \\
\hline & & & & & & & & $(\mathrm{Kg})$ & & \\
\hline${ }^{(1)} \sigma^{2} G$ & 0.23 & 0.48 & 1.96 & 3.51 & 274654.82 & 18.29 & 19.32 & 0.09 & 16.97 & 1.49 \\
\hline$\sigma^{2} \mathrm{INT}$ & 1.56 & 2.67 & 7.09 & 2.26 & 296959.68 & 94.98 & 122.68 & 0.53 & 294.21 & 6.09 \\
\hline$\sigma^{2} E$ & 2.03 & 4.57 & 10.38 & 5.57 & 494384.68 & 33.60 & 74.81 & 0.20 & 92.43 & 1.44 \\
\hline$\sigma^{2} \mathrm{P}$ & 3.82 & 7.72 & 19.44 & 11.35 & 1065999.18 & 146.86 & 216.80 & 0.82 & 403.60 & 9.03 \\
\hline$\hat{\mathrm{h}}_{\mathrm{a}}^{2}$ & 0.06 & 0.06 & 0.10 & 0.31 & 0.26 & 0.12 & 0.09 & 0.11 & 0.04 & 0.17 \\
\hline$\hat{\mathrm{h}}_{\mathrm{mg}}^{2}$ & 0.34 & 0.37 & 0.48 & 0.81 & 0.75 & 0.46 & 0.40 & 0.44 & 0.17 & 0.53 \\
\hline$\hat{r}_{g \hat{g}}$ & 0.59 & 0.61 & 0.69 & 0.90 & 0.87 & 0.68 & 0.63 & 0.66 & 0.41 & 0.73 \\
\hline$C_{g}^{2}$ & 0.41 & 0.35 & 0.37 & 0.20 & 0.28 & 0.65 & 0.57 & 0.65 & 0.73 & 0.68 \\
\hline$\hat{r}_{\text {gloc }}$ & 0.13 & 0.15 & 0.22 & 0.61 & 0.48 & 0.16 & 0.14 & 0.15 & 0.06 & 0.20 \\
\hline $\mathrm{CV}_{\mathrm{g}}(\%)$ & 2.02 & 2.88 & 2.32 & 11.96 & 6.87 & 3.62 & 1.92 & 3.88 & 2.27 & 3.74 \\
\hline $\mathrm{CV}_{\mathrm{e}}(\%)$ & 5.97 & 8.85 & 5.33 & 15.07 & 9.22 & 4.90 & 3.78 & 5.71 & 5.29 & 3.68 \\
\hline OM & 23.90 & 24.15 & 60.46 & 15.67 & 7624.94 & 118.20 & 228.57 & 7.80 & 181.86 & 32.63 \\
\hline
\end{tabular}

${ }^{(1)} \sigma^{2} G$ - genotypic variance; $\sigma^{2} \mathrm{INT}$ - variance of genotype $\mathrm{x}$ environment interaction; $\sigma^{2} \mathrm{E}$ - residual variance between plots; $\sigma^{2} \mathrm{P}$ - individual phenotypic variance; $\hat{\mathrm{h}}_{\mathrm{a}}^{2}$ - individual heritability coefficient in the broad sense; $\hat{\mathrm{h}}_{\mathrm{mg}}^{2}$ - genotype mean heritability; $\hat{r}_{\mathrm{g}} \hat{\mathrm{g}}$ - selective accuracy; $\mathrm{C}_{\mathrm{g}}^{2}$ - coefficient of determination of the effects of genotype $\mathrm{x}$ environment interaction; $\hat{\mathrm{r}}_{\mathrm{gloc}}$ - genotypic correlation between performance in several environments; $\mathrm{CV}_{g}(\%)$ - genetic coefficient of variation; $\mathrm{CV}_{\mathrm{e}}(\%)$ - residual coefficient of variation, and OM - overall mean. (2)SD - stem diameter in mm; LA - leaf angle, in degrees; TL - tassel length, in $\mathrm{cm}$; $\mathrm{BN}$ - tassel branch number in units; TLA - total leaf area in $\mathrm{cm}^{2}$; $\mathrm{EH}$ - ear insertion height, in cm; e PH - Plant height, in cm; GY - plot grain yield, in kg; GM - ear grains total mass, in g; HGM - a hundred grains mass, in $\mathrm{g}$.

Estimates genotype $x$ environment interaction variance $\left(\sigma^{2} \mathrm{INT}\right)$ can inflate a character phenotypic expression, since this estimate shows how much of the total variance is represented by GxA interaction. To Maia et al. (2009), $\sigma^{2}{ }^{2} \mathrm{NT}$ small magnitudes indicate that interaction little influenced phenotypic value, and in this context, a genotype with good performance in an environment would tend to maintain this performance in diverse environments, since the phenotype would favorably respond to environmental influences, keeping also behavioral consistency or predictability in front of environmental changes. The magnitude of this work for interaction variance were significant, ranging from $72.9 \%$ for GM to $19.9 \%$ for the total phenotypic variation $\mathrm{BN}$, showing that intrinsic characteristics inherent in hybrids cultivation environments generated a strong influence on phenotypic expression. This proportion resulted in a genotypic performance correlation $\left(\hat{r}_{\text {gloc }}\right)$ in environments, with the largest amplitudes registered for BN (0.61) and TLA (0.48) characters and the smallest for $\mathrm{GM}(0.06)$ and $\mathrm{SD}(0.13)$. This reveals the presence of complex type GxA interaction (Cruz et al., 2012). Rosado et al. (2012) reports a tendency in maintaining superiority order in the different environments at magnitudes of $\hat{r}_{\text {gloc }}>0.50$.

Genetic variation coefficient $\left(\mathrm{CV}_{g}\right)$ is an important factor to be considered, because if it is low, it will provide a more limited scope selection. Genetic variation coefficients $\left(\mathrm{CV}_{\mathrm{g}}\right)$ had magnitudes ranging from $11.96 \%$ for $\mathrm{BN}$ to $1.92 \%$ to $\mathrm{PH}$ at all sites, indicating the presence of considerable genetic variability, with possibility to perform superior hybrids effective selection.

Residual variation coefficients $\left(\mathrm{CV}_{\mathrm{e}}\right)$ showed values ranging between moderate and low, confirming good experimental precision. The highest magnitudes were for $\mathrm{BN}$ and TLA characters $(15.67 \%$ and $9.22 \%$, respectively), while the smallest were for $\mathrm{HMG}$ and $\mathrm{PH}$ characters (3.68\% and $3.78 \%$, respectively). $\mathrm{CV}_{\mathrm{g}}$ and $\mathrm{CV}_{\mathrm{e}}$ values reflect the magnitude of selective $\operatorname{accuracy}\left(\hat{r}_{g}\right)$, which showed the highest magnitudes for BN (0.90) and TLA (0.87) characters, while GM $(0.41)$ and SD (0.59) showed the lowest magnitudes. One of the possible causes that may have revealed reduced $\hat{r}_{g}$ magnitudes may be due to the reduced number of replicates used for location, which where three. According to Resende \& Duarte (2007), using two to four repetitions, it is not possible to achieve desired accuracy levels, since under low repetitions number, an accuracy of $90 \%$ could be achieved only with high genetic determination coefficient characters $\left(h_{i}^{2} \geq 0.60\right)$ a fact that is unlikely to quantitative characters. Thus, the same authors recommend that for production characters with $h_{i}^{2} \leq 0.40$, at least six replicates would be needed.

Coefficient of determination of the effects of genotype $x$ environment interaction $\left(\mathrm{C}_{\mathrm{g}}^{2}\right)$ estimations showed that particularities of the cultivation sites in 
which hybrids were analyzed influenced characters phenotypic expression, with the largest magnitudes revealed for GM (0.73), HGM (0.68), EH (0.65) and GY (0.65) (Table 1). Through $\mathrm{C}_{\mathrm{g}}^{2}$ it is possible to estimate genotype behavior constancy or predictability front of environmental variations (Rosado et al., 2012)

Estimates of genotypic correlation coefficients between pairs of character combinations are shown in Table 2. With respect to the magnitude of the correlation coefficients between characters, there was a variation from 0.007 to 0.877 . In the studied environments, positive and significant correlations were found between $\mathrm{EH}$ (0.291), PH (0.307), GM (0.540), HGM (0.480), SD (0.168) and TLA (0.379) characters with GY character, indicating that the increase of these characters in the selection of corn hybrids have potential for increasing grain yield. These results corroborate with those found by Hallauer et al. (2010).

Regarding SD character, Sangoi et al. (2001) reported that the stem contains a large photoassimilates reserve that can be translocated to the grains when the referred source is not sufficient, a situation observed especially during plant senescence. In addition, there is the stem role as a modulator organ in the restriction imposed on the leaves, reducing the damage caused by defoliation in grain yield. On the
TLA character, Brito et al. (2011) mentioned that the productive potential of a hybrid is directly related to its leaf area, saying that severe leaf area losses more than $40 \%$ at the beginning of grain filling can compromise crop grains performance. Alvim et al. (2011) observed that the loss of physiologically active leaf area above the corn ear greatly reduces grain yield, affects cobs density and compromises the integrity of stem and roots, making the plant susceptible to lodging and steam breaking.

On the other hand, the TL character (-0.542) showed negative correlation with GY. This fact leads to a decrease in the grain yield character. Sofi (2007) reported that generally lower yields have been observed in plants with larger tassels due to higher photoassimilates allocation by the plant. Thus, breeders have directed selection to smaller tassels, as this has been negatively correlated with grain yield. In this context, modern corn hybrids produce lower tassels that require smaller amounts of nutrients and photoassimilates to support their development (Sangoi \& Salvador, 1998). Thus, the lower demand power and lower tassel apical dominance over the ears are major causes for the higher number of ears per plant and better floral timing of corn hybrids, especially under high sowing densities (Sangoi et al., 2002).

Table 2 - Estimates of genetic correlations for 25 corn hybrids, referring to five sowing sites in southern Brazil.

\begin{tabular}{|c|c|c|c|c|c|c|c|c|c|}
\hline & $\mathrm{PH}^{(1)}$ & GY & GM & HGM & SD & LA & TL & BN & TLA \\
\hline$\overline{\mathrm{EH}}$ & $0.877^{* *}$ & $0.291^{* *}$ & $0.128^{*}$ & $0.524^{* *}$ & $0.051^{\mathrm{ns}}$ & $0.285^{\star *}$ & $-0.564^{* *}$ & $0.042^{\text {ns }}$ & $0.083^{\text {ns }}$ \\
\hline $\mathrm{PH}$ & - & $0.307^{\star *}$ & $0.069^{\text {ns }}$ & $0.428^{* *}$ & $0.360^{* *}$ & $0.342^{\star \star}$ & $-0.464^{\star *}$ & $0.143^{* *}$ & $-0.087^{\mathrm{ns}}$ \\
\hline GY & & - & $0.540^{* *}$ & $0.480^{* *}$ & $0.168^{\star *}$ & $-0.024^{\mathrm{ns}}$ & $-0.542^{\star *}$ & $-0.075^{\mathrm{ns}}$ & $0.379^{\star *}$ \\
\hline GM & & & - & $0.393^{\star *}$ & $0.007^{\text {ns }}$ & $-0.294^{\star \star}$ & $-0.395^{\star \star}$ & $-0.012^{\text {ns }}$ & $0.304^{\text {** }}$ \\
\hline HGM & & & & - & $-0.080^{n s}$ & $0.264^{\star *}$ & $-0.192^{\star *}$ & $-0.173^{\star *}$ & $0.113^{*}$ \\
\hline SD & & & & & - & 0.450 ** & $0.100^{\text {ns }}$ & $0.465^{\star *}$ & $-0.294^{* *}$ \\
\hline LA & & & & & & - & $0.270^{* *}$ & $0.387^{* *}$ & $-0.659^{* *}$ \\
\hline TL & & & & & & & - & $0.121^{*}$ & $-0.392^{\star *}$ \\
\hline $\mathrm{BN}$ & & & & & & & & - & $-0.250^{\star *}$ \\
\hline
\end{tabular}

${ }^{\star \star},{ }^{*}$ Significant by $t$ test at 0.01 and 0.05 probability, respectively with 375 error freedom degrees. ${ }^{\text {ns }}$ not significant by $t$ test at 0.05 probability, respectively, with 375 error freedom degrees. ${ }^{(1)} \mathrm{GY}$ - plot grain yield, in $\mathrm{kg}$; $\mathrm{GM}$ - ear grains total mass, in g; HGM - a hundred grains mass, in g; $\mathrm{EH}$ - ear insertion height, in cm; PH - Plant height, in cm; $A$; SD -stem diameter, in mm; LA - leaf angle, in degrees; TL - tassel length, in cm; BN - tassel branch number, in units; TLA - total leaf area, in $\mathrm{cm}^{2}$.

There were significant and positive correlations between EH (0.128), HGM (0.393) and TLA (0.304) characters with GM character, as well as negative correlation between GM, LA (-0.294) and TL (-0.395). Positive correlation estimates indicate a tendency of a variable to increase when the other increases or simultaneous decrease of both variables, while negative correlations estimates indicate a tendency to increase a variable while other decreases.

HGM character revealed significant correlations of positive magnitude with $\mathrm{EH}(0.524), \mathrm{PH}$ (0.428), LA (0.264) and TLA (0.113), showing that a selection based on these characters tend to indirectly increase corn HGM. Negative and significant correlations are also highlighted, which were observed between HGM TH $(-0.192)$ and BN $(-0.173)$, revealing a negative influence of tassel morphological characters in the HGM. Tassel can affect grain yield and its components, because of the light interception reduction in plants canopy, as well as the use of carbohydrate sources. Mickelson et al. (2002) reported that detasseled plants had $19 \%$ more yield compared to plants showing intact tassels, revealing that tassel shading was the main determinant on corn production.

Estimates of correlations and canonical pairs of agronomic characters of yield components (Group I) and morphological characters (Group II), as well as the significance level, are presented in Table 3. The three canonical pairs turn out to be significant at $1 \%$ probability level $(p<0.01)$ by chi-square test. Therefore, the three canonical pairs are of interest to the study. It is found that by magnitude of the canonical correlations revealed among pairs, considered groups are not independent. 
Table 3 - Estimates of correlations and canonical pairs between agronomic yield components (Group I) and morphological characters (Group II), in 25 corn hybrids, referring to five sowing sites in southern Brazil.

\begin{tabular}{lrrr}
\hline \multirow{2}{*}{${ }^{(1)}$ Characters } & \multicolumn{3}{c}{ Canonical pairs } \\
\cline { 2 - 4 } & \multicolumn{1}{c}{$1^{\text {st }}$} & $2^{\text {nd }}$ & $3^{\text {rd }}$ \\
GY & Group I & 0.2505 \\
GM & 0.1661 & 0.9538 & 0.8630 \\
HGM & -0.3157 & 0.3945 & 0.6335 \\
EH & 0.7455 & 0.2070 & 0.6672 \\
PH & Group II & 0.3580 \\
SD & 0.5594 & & -0.3261 \\
LA & 0.4998 & 0.2199 & -0.3592 \\
TL & -0.0850 & 0.2930 & -0.5486 \\
BN & 0.5987 & -0.1020 & -0.1712 \\
TLA & 0.0691 & -0.7082 & 0.4258 \\
\hline$r$ & -0.2109 & -0.0441 & 0.3586 \\
\hline$\alpha$ & -0.1004 & 0.4998 & $<0.01$ \\
\hline
\end{tabular}

(1)GY- plot grain yield, in kg; GM - ear grains total mass, in g; HGM - a hundred grains mass, in g; EH - ear insertion height, in $\mathrm{cm}$; PH - Plant height, in cm; SD - stem diameter, in mm; LA - leaf angle, in degrees; TL - tassel length, in cm; BN - tassel branch number, in units; TLA - total leaf area, in $\mathrm{cm}^{2}$.

From Table 3, it is found that the association between groups are established by the influence of:

i) the first canonical pair with 0.8095 correlation associates plants with higher $\mathrm{EH}, \mathrm{PH}$ and $\mathrm{LA}$, as well as lower BN (group II characters) as determinant to HGM increase (Group I characters). Through correlations evidenced in this canonical pair, corn hybrids with higher plant height, ear insertion and leaf angle and lower tassel branches are important for increasing corn grain yield. However, for plant height and ear insertion characters, some caution should be taken, since plant height and ear insertion reduction were important changes to a more efficient nitrogen use (Sangoi et al., 2002). In addition, it allowed the plant's center of gravity to stay more balanced, reducing lodging and steam breakage and favoring nutrient transport and plant production (Sangoi et al., 2002). Câmara et al. (2007), by linear correlation analysis, showed no significant magnitudes between tassel branch with grain yield, although good experimental conditions and tassels with a small number of branches were responsible for minimized the competition between ear and tassel, thereby reducing the effects of branches number.

Competition intensity between tassel and ear is related to environmental conditions and the type of management used in culture, and restrictions on water availability and plant populations excessive increments are factors that stimulate tassel apical dominance over ears (Sangoi \& Salvador, 1998). Duvick (2005) suggests a reduction in the number of tassel branches, in a study with corn hybrids in lowa (United States of America), in a time series from 1930 to 1991, indicating an average reduction of 2.5 branches per decade. In this study, corn hybrids from various selection cycles were treated, with a very similar pattern among the hybrids, i.e., few branches. Probably there was no direct negative relation between the number of branches with grain yield, precisely due to the character being very similar between hybrids.

ii) in the second canonical pair, with 0.7431 correlation, the relation between plants that had a higher TLA and lower TL (group II characters) as determinants of GY increase (group I characters) was observed. The results of this second canonical pair indicate that plants with higher leaf area, as well as shorter tassel length are favorable for increasing grain yield. Duvick (2005) reported on a study conducted with corn hybrids in lowa, in a time series from 1930 to 1991, an average reduction of 0.5 grams per decade in tassel dry weight. Likewise, Sangoi et al. (2006), while carrying out tassel removal in commercial corn hybrids, showed significant grain yield increase, $7 \%$, in the mean yield of analyzed genotypes.

Corn, due to presenting determinate growth habit, does not expand new leaves after flowering, and thus can compromise grain filling if the exposed leaves are damaged. With the elimination of leaf area, photosynthetic active radiation is not intercepted, hampering photosynthesis (Sangoi et al., 2014).

iii) the third canonical pair, with 0.3586 correlation, associate genotypes with the highest $\mathrm{EH}$ and TLA, as well as lower TL (group II characters) as a key to higher GM and HGM (Group I characters). Thus, plants with a higher ear insertion height, leaf area and shorter tassel length are in favor to raise grain mass and a one hundred corn grains mass. $\mathrm{CO}_{2}$ fixation through photosynthesis is responsible for about $90 \%$ of corn dry matter mass (Magalhães et al. 2002). Since photosynthesis is dependent on leaf area, a culture yield reveal yield increase the higher its leaf area index is as well as long that leaf area remains active, delaying senescence (Ceppi et al., 1987).

These results may help breeders, in practice, to achieve higher efficiency through simultaneous character selection, aiming at promising hybrid in breeding process. However, repetition with other genotypes and/or environments is recommended for further elucidation and results understanding. 


\section{Conclusions}

Significant correlations estimates among the three canonical pairs indicate that the groups are not independent.

For grain mass increase, hybrids with higher ear insertion height, leaf area and shorter tassel length should be considered.

Increased leaf area and shorter tassel length are favorably related with increasing corn grain yield.

\section{Acknowledgments}

The authors thank the Higher Education Personnel Training Coordination (CAPES), for the project financing and for the granting of the first author's doctoral scholarship, and the KSP Sementes Ltda. company for providing the inbred lines bank used in this study

\section{References}

Alvim KRT, Brito CH, Brandão AM, Gomes LS, Lopes MG (2011). Redução da área foliar em plantas de milho na fase reprodutiva. Revista Ceres, 58 (4): 413-418.

Brito CH, Silveira, DL, Brandão AM, Gomes LS, Lopes MTG (2011). Redução de área foliar em milho em região tropical no Brasil e os efeitos em caracteres agronômicos. Interciência, 36 (4): 291-295.

Brum B, Lopes SJ, Storck L, Lúcio ADC, Oliveira PHD, Milani M (2011) Correlações canônicas entre variáveis de semente, plântula, planta e produção de grãos em mamoneira. Ciência Rural 41 (3): 404-411.

Câmara TMM, Bento DAV, Alves GF, Santos MF, Moreira JUV, Souza Júnior CL (2007) Parâmetros genéticos de caracteres relacionados à tolerância à deficiência hídrica em milho tropical. Bragantia 66 (4): 595-603.

Carvalho FIF, Silva SA, Kurek AJ, Marchioro VS (2001) Estimativas e implicações da herdabilidade como estratégia de seleção. Pelotas: UFPel, 99p.

Ceppi D, Sala M, Gentinetta E, Verderio A, Motto M (1987) Genotype-dependent leaf senescence in maize: inheritance and effects of pollination-prevention. Plant Physiology 85 (3): 720-725.

Coimbra JLM, Guidolin AF, Carvalho FIF (2000) Azevedo, R. Correlações canônicas: II - Análise do rendimento de grãos de feijão e seus componentes. Ciência Rural 30(1): 31-35.

CONAB - Companhia Nacional de Abastecimento. Acompanhamento da Safra Brasileira. Disponível em:<http://www.conab.gov.br/OlalaCMS/uploads/arq uivos/14_05_08_10_11_00_boletim_graos_maio_20 14.pdf> Acesso em: 05 mai. 2014.
Cruz CD, Regazzi AJ, Carneiro PCS (2012) Modelos biométricos aplicados ao melhoramento genético. Viçosa: UFV. 514p.

Cruz CD (2006) Programa Genes: Biometria. Editora UFV. Viçosa (MG) 382p.

Duvick DN (2005) The Contribution of Breeding to Yield Advances in maize (Zea mays L.). Advances in Agronomy, 86, Copyright. 63p.

Embrapa - Empresa Brasileira de Pesquisa Agropecuária (2010) Cultivo do Milho. Versão Eletrônica. 6.ed. [S1.]: Embrapa Milho e Sorgo.

Hallauer AR, Carena MJ, Miranda Filho JB (2010) Quantitative genetics in maize breeding. Springer, $663 p$.

Hazel LN (1943) The Genetic Basis for Constructing Selection Indexes. Genetics 28(6): 476-90

Maia MCC, Resende, MDV, Paiva JR, Cavalcanti JJV, Barros LM (2009) Seleção simultânea para produção, adaptabilidade e estabilidade genotípicas em clones de cajueiro, via modelos mistos. Pesquisa Agropecuária Tropical 39(1) 43-50.

Magalhães PC, Durães FOM, Paiva E, Carneiro NP, Paiva E (2002) Fisiologia do milho. Sete Lagoas: EMBRAPA - CNPMS, (EMBRAPA-CNPMS. Circular Técnica, 22). $23 \mathrm{p}$.

Mickelson SM, Stuber CS, Senior L, Kaeppler SM (2002) Quantitative trait loci controlling leaf and tassel traits in a B73 $\times$ Mo17 population of maize. Crop Science 42(6): 1902-1909.

Mode CJ, Robinson HF (1959) Pleiotropism and the Genetic Variance and Covariance. Biometrics 15: 518537.

Protásio TP, Tonoli GHD, Júnior MG, Bufalino L, Couto AM, Trugilho PF (2012) Correlações canônicas entre as características químicas e energéticas de resíduos lignocelulósicos. Cerne 18(3): 433-439.

Rosado AM, Rosado TB, Alves AA, Laviola BG, Bhering LL (2012) Seleção simultânea de clones de eucalipto de acordo com produtividade, estabilidade e adaptabilidade. Pesquisa Agropecuária Brasileira 47 (7): 964-971.

Resende MDV (2002) Genética biométrica e estatística no melhoramento de plantas perenes. Brasília: Embrapa Informação Tecnológica; Colombo: Embrapa Florestas, 975 p.

Resende MDV (2007) Software Selegem REML/BLUP: Sistema estatístico e seleção genética computadorizada via modelos lineares mistos. Colombo: Embrapa Florestas, 350p.

Resende MDV, Duarte JB (2007) Precisão e controle de qualidade em experimentos de avaliação de cultivares. Pesquisa Agropecuária Tropical 37(3) 182194. 
Rigão MH, Storck L, Bisognin DA, Lopes SJ (2009) Canonical correlation for tuber trait to assist early selection of potato clones. Ciência Rural 39(8): 2347$-2353$.

Sangoi L, Junior GJP, Vargas VP, Vieira J, Schmitt A, Zoldan SR, Siega E, Carniel G (2014) Cobertura nitrogenada como estratégia para reduzir os prejuízos da desfolha em diferentes estádios fenológicos do milho. Semina: Ciências Agrárias 35(2): 671-682.

Sangoi L, Guidolin AF, Coimbra JLM, Silva PRFD (2006) Resposta de híbridos de milho cultivados em diferentes épocas à população de plantas e ao despendoamento. Ciencia Rural 36(5): 1367-1373.

Sangoi L, Almeida ML, Silva PRF, Argenta G (2002) Bases morfofisiológicas para maior tolerância dos híbridos modernos de milho a altas densidades de plantas. Bragantia 61:(2) 101-110.

Sangoi L, Lech VA, Rampazzo C, Gracietti M (2001) Desempenho de híbridos de milho com ciclos contrastantes em função da desfolha e da população de plantas. Scientia Agricola 58(2): 271-276.
Sangoi L, Salvador RJ (1998) Effect of maize plant detasseling on grain yield tolerance at high plant density and drought stress. Pesquisa Agropecuária Brasileira 33(5): 677-684.

Silva JW, Soares L, Ferreira PV, Silva PP, Silva MJC (2007) Correlações canônicas de características agroindustriais em cana-de-açúcar. Acta Scientiarum: Agronomy 29 (3): 345-349.

Sofi PA (2007). Genetic Analysis of Tassel and Ear Characters in Maize (Zea mays L.) Using Triple Test Cross. Asian Journal of Plant Sciences, 6(5) 881-883.

Steel RGD, Torrie JH (1980) Analysis of covariance. Principles and procedures of statistics: A Biometrical Approach. New York: McGraw-Hill, 401-437

Trugilho PF, Lima JT, Mori FA (2003) Correlação canônica das características químicas e físicas da madeira de clones de Eucalyptus grandis e Eucalyptus saligna. Cerne 9(1): 66-80. 